ISTIGHNA, Vol. 3, No 1, Januari 2020 P-ISSN 1979-2824 E-ISSN 2655-8459

Homepage: http://e-journal.stit-islamic-village.ac.id/index.php/istighna

Chindi Ayu Shonia, Lia Hermawati

Pemikiran Politik Abu A'la Almaududi

\title{
PEMIKIRAN POLITIK ABU A’LA ALMAUDUDI
}

\author{
Chindi Ayu Shonia \\ chindiayushonia89@gmail.com \\ Universitas Sriwijaya; jalan Palembang-Prabumulih KM 32, Kabupaten Ogan Ilir, \\ Sumatera Selatan, (0711) 580169, mail@unsri.ac.id
}

\section{Lia Hermawati}

liahermawati1807@gmail.com

Universitas Sriwijaya; jalan Palembang-Prabumulih KM 32, Kabupaten Ogan Ilir, Sumatera Selatan, (0711) 580169, mail@unsri.ac.id

\begin{abstract}
Studying Islam and its political affiliation in the Islamic world is one of the most never-ending studies. Various theories that have been introduced and introduced by various scholars from the early medieval period to the modern intellectuals of the West, though they are not very convinced of Islam, are also involved in the search for a new formula for the nature of the attitude. should be Islamic religion and politics. This article will examine the political views of Abu a'la Al Maududi, a leading figure, a Muslim political thinker from Pakistan who introduced a synthesis to reconcile Western secular democracy with the concept of Islamic theocracy.
\end{abstract}

\section{Keywords: Thought, Politics, Abu A'la al-Maududi}

\begin{abstract}
Abstrak: Mengkaji mengenai hubungan islam dan politiknya dalam dunia islam merupakan salah satu kajian yang tidak pernah berhenti. Macam-macam teori yang telah dikemukakan serta diperkenalkan oleh berbagai pihak-pihak cendekiawan baik masa klaasik hingga modern tak ketinggalan juga, kaum intelektual dari Barat, walaupun mereka tidak terlalu percaya denganpaham agama Islam, tetapi juga ikut terlibat kedalam pencarian rumus baru mengenai bagiamana sikap yang seharusnya hubungan agama Islam dan politik. Artikel ini akan mencoba menelaah pandangan politik Abu a'la Al Mawdudi, merupakan seorang tokoh yang terkemuka, seorang pemikir politik Muslim dari Pakistan yang memperkenalkan suatu sintesa untuk mendamaikan faham demokrasi sekuler Barat dengan konsep teokrasi Islam.
\end{abstract}

Kata kunci: Pemikiran, Politik, Abu A'la al-Maududi

Peer reviewed under reponsibility of STIT ISLAMIC VILLAGE.

(C) 2018 STIT ISLAMIC VILLAGE, All right reserved, This is an open access article under 12 the CC BY SA license (https://creativecommons.org/licenses/by-sa/4.0/) 
ISTIGHNA, Vol. 3, No 1, Januari 2020 P-ISSN 1979-2824 E-ISSN 2655-8459

Homepage: http://e-journal.stit-islamic-village.ac.id/index.php/istighna

Chindi Ayu Shonia, Lia Hermawati Pemikiran Politik Abu A'la Almaududi

\section{A. PENDAHULUAN}

Terdapat banyak hal penyebab mengapa literasi mengenai pendirian Khalifah Islamiyah ini kembali muncul. Beberapa sebabnya yaitu: pertama dikarenakan adanya tekanan rezim politik yang berkuasa yang hidup dibawah bayangan kepentingan pihak barat. Sekolompok umat islam tertentu tidak mendapatkan haknya untuk mengungkapkan pendapat. Kedua yaitu karena ketidakberhasilan dari paham dari pihak yang berkuasa. Dengan gosip-gosip modernitas ternyata tidak juga berhasil membuat umat Islam ke dalam suatu kondisi yang prima bahkan semakin jatuh dari segi ekonomi,politik, hingga budaya, bahkan hingga ke segi pendangkalan paham agama.

Sehingga begitu, kehadiran dasar agama menjadi anggapan sebagai pilihan yang sebenarnya bagi umat Islam dan diharapkan dapat membuat umat islam kembali pada keemasannya dengan mempedomani kepada Al-Quran dan hadis nabi. Salah satu cara untuk mengembalikan keemasan islam zaman dahulu tidak terdapat cara lain selain membentuk serta mewujdukan suatu negara Islam sebagai sebuah tindakan nyata pelaksanaan syariat Islam secara penuh. Sebab sebuah kelompok bahwa Islam adalah keyakinan sekaligus negara.

Politik dan agama adalah dua hal yang tidak dapat dipisahkan dalam Islam, tetapi terdapat keterkaitan diantaranya keduanya. Didalam kitab suci Al-quran serta perkataan nabi mengenai bagaimana bentuk dan pemerintahan yang tepat untuk agama Islam tidak dijelaskan secara rinci namun kedua memberi ajaran tata nilai serta etika bagaimana mengatur sebuah kehidupan bernegara maupun masyarakat. Nabi Muhammad menjadikan negara sebuah instrumen untuk umat islam mengembangkan serta menyebarkan agama.

Opini serupa bahkan lebih tegas mengenai hubungan antara Islam serta negara dinyataan oleh al- Mawdudi ia mengungkapkan secara lebih tegas bahwa Islam bersama Al-quran tak hanya berisikan ibadah,moral,serta etika saja. Tetapi didalamnya juga terdapat tuntunan dala bidang sosial, politik,serta ekonomi bahkan mengai hukum negara serta institusi kenegaraan. Berbagai macam aturan yang ada 
ISTIGHNA, Vol. 3, No 1, Januari 2020 P-ISSN 1979-2824 E-ISSN 2655-8459

Homepage: http://e-journal.stit-islamic-village.ac.id/index.php/istighna

Chindi Ayu Shonia, Lia Hermawati Pemikiran Politik Abu A'la Almaududi

dalam al-Quran mestilah diwujudkan dalam kenyataan salah satu caranya yaitu dengan mendirikan agama islam yang berbasis hukum islam secara utuh. Menurutnya kita haruslah menegaskan hukum ilahi sejajar dengannya serta menjadi aturannya sebagai undang-undang negara. Ia juga memberikan tambahan, apabila langkah ini tidak dilakukan maka tidak akan dapat untuk menegakkan agama secara sempurna tapi jika sebagian kecil saja dari agama, dan jikalau ini terjadi maka akan terjadi penolakan atas agama itu sendiri.

Dalam hal ini pemikiran Abu A'la Almawdudi yang secara tegas berkomentar perihal betapa pentingnya negara Islam. Bahkan lebih dari itu, pemikiran Abu Al-Mawdudi terkait dengan negara Islam merupakan sebuah pemikiran yang paling lengkap dan berkelanjutan dibandingkan dengan beberapa pemikir Islam kontemporer lainnya. Tulisan ini berusaha untuk melihat secara intensif pemikiran politik Abu A'la Al-Mawdudi yang berserakan dengan sejumlah karyanya. Hal ini penting sebagai suatu alasan mengingat pemikiranpemikirannnya disenangi serta dijadikan padnuan oleh beberapa organisasi masyarakat kegamaan.di Indonesia.

\section{B. METODE PENELITIAN}

Metode yang dipakai dalam kepenulisan atrikel ini adalah metode atau library research (pendekatan kepustakaan), Studi pustaka atau kepustakaan merupakan serangkaian aktivitas yang berkaitan dengan metode penghimpunan data pustaka, membaca dan menulis kemudian mengolah bahan untuk penelitian. ${ }^{1}$ Dalam penelitian menggunakan metode studi pustaka terdapat 4 ciri utama yang perlu penulis perhatikan yaitu: Pertama, penulis/peneliti menghadapi langsung teks (naskah) atau data berupa angka, bukan data dari pengetahuan saat penelitian langsung di lapangan. Kedua, data pustaka memiliki sifat "siap pakai" artinya peneliti tidak perlu turun langsung kelapangan karena peneliti menghadapi langsung sumber data yang terdapat di perpustakaan. Ketiga, data pustaka pada umumnya adalah sumber yang bersifat sekunder, dalam arti bahwa peneliti

\footnotetext{
${ }^{1}$ Mestika Zed, Metode Penelitian Kepustakaan, Jakarta: Yayasan Obor Indonesia, 2004, hlm 3
} 
ISTIGHNA, Vol. 3, No 1, Januari 2020 P-ISSN 1979-2824 E-ISSN 2655-8459

Homepage: http://e-journal.stit-islamic-village.ac.id/index.php/istighna

Chindi Ayu Shonia, Lia Hermawati Pemikiran Politik Abu A'la Almaududi

mendapatkan bahan/data dari pihak kedua dan bukan merupakan data asli dari pihak pertama di lapangan. Keempat, kondisi data pustaka terbatas oleh waktu dan ruang. ${ }^{2}$ Berlandaskan pada ciri-ciri diatas, maka penghimpunan data pada penelitian dilakukan dengan mempelajari dan/atau mendalami sejumlah buku, Jurnal, dan dokumen-dokumen (baik dalam bentuk cetak ataupun elektronik) beserta sumbersumber data dan/atau informasi lainnya yang diperkirakan berkaitan dengan penelitian/kajian.

\section{HASIL DAN PEMBAHASAN}

Abu A'la Al Mawdudi dilahirkan di Aungabad, pada 3 Rajab $1321 \mathrm{H}$ atau 25 September 1903 M. kota Aungabad merupakan kota terkenal di kesultanan Hyderabad (Decan) yang sekarang ini masuk diwilayah Andhra Predes India. Jika ditengok dari garis silsilah keturunannya ia berasal dari keluarga yang terhormat. Nenek moyangnya dari garis Ayah yang merupakan keturunan nabi Muhammad Saw, maka dari itu pada namanya ia memakai nama "Sayyid". 3

Maududi berasal dari keluarga yang agamamis. Ayahnya yang mendidik dari pendidikan dasar dan beberapa tutor yang didatangkan kerumahnya ikut berperan. Saat masih kecil beliau belajar bahasa Urdu, Persia, Arab, Fiqh, dan Hadist. Ayahnya memnginginkan jika Maududi menjadi seorang Maulai, dan tidak memperbolehkan maududi belajar bahsa inggris. Namun akhirnya beliau memepelajari bahsa inggri dan berbagai disiplin ilmu pengetahuan modern lainnya setelah sang ayah meninggal dunia. Pemikiran yang mempengaruhi dirinya dan berperang penting dalam pembentukan pemikirannya yaitu pemikiran dari ibnu taimiyah, ibnu Qoyim, dan Syah Waliullah. ${ }^{4}$

Nenek moyang al-Mawudui berasal dari para syaikh besar pengikut tarekat Chistiyah jika dilihat dari catatan sejarah serta karya-karyanya. Tarekat ini banyak

\footnotetext{
${ }^{2}$ Ibid, hlm 4-5

${ }^{3}$ Kesuma dkk, Pemikiran Politik Abu A'la Al Mawdudi, IAIN Raden Intan Lampung, 2015, hlm 326

${ }^{4}$ Ainur Ropik, Studi Komparasi Pemikiran Abul A'la Maududi Dengan Muhammad Natsir Tentang Konsep Negara Islam, Palembang: IAIN Raden Fatah, 2012, hlm 174-175
} 
ISTIGHNA, Vol. 3, No 1, Januari 2020 P-ISSN 1979-2824 E-ISSN 2655-8459

Homepage: http://e-journal.stit-islamic-village.ac.id/index.php/istighna

Chindi Ayu Shonia, Lia Hermawati Pemikiran Politik Abu A'la Almaududi

berperan dalam dalam penyebaran dan pengembangan islam di India. Dilihat dari sejarah keluarga Al-Mawdudi memiliki hubungan erat dengan dinasti Moghul, utamanya pada pemerintahan Bahadur Syah Zhafar (penguasa terakhir). ${ }^{5}$ Hal yang menarik juga berkaitan dengan nama tokoh yang akan dibahas ini adalah jika dilhat dari namanya. Abu A'la berarti ayah dari yang maha kuasa. Nama tokoh ini mendapatkan banyak kritikan dari pihak-pihak khusus. Maka Al Maududi merasa kesal dan merasa tidak nyaman akan kritikan yang menuju kepadanya itu. Ahmaad Hasan sendiri selaku ayah pun turut memberikan penjelasan mengenai nama anaknya tersebut. Ia berkata bahwa pada tiga tahun sebelum al-Mawdudi lahir,seseorang yang suci mendatanginya dan mengatakan padanya bahwa Allah Swt akan memberkahinya seorang anak laki-laki yang ditakdirkan akan besar dan berbakti pada agamanya. ${ }^{6}$

Kemudian ia mendatangi tokoh sufi yang terkenal dikotanya, tokoh sufi tersebut mengatakan bahwa Allah akan memberikannya putra yang suatu hari nanti akan dihormati serta mendapatkan kedudukan yang tinggi, dan di ujung ceritanya tokoh sufi ini berpesan agar memberikan nama kepada putra tersebut nama Abu alA'la. Setelah mendengar berita baik itu, Ayah al-Maududi sangat berbahagia dan mengharapkan kabar tersebut akan menjadi kenyataan. ${ }^{7}$

Samir Abdul Hamid Ibrahim mengatakan bahwa nama al-Mawdudi merupakan nama sebuah keluarga yang garis keturunannya telah terdapat sebuah keluarga yang garis keturunannya telah ada sejak 300 tahun yang lalu. Nenek moyang yang pertama datang berasal dari Jarirah Arab dan tinggal disuatu tempat yang bernama "Jasyat", yang tidak jauh dari kota Harat. Dan dipenghujug abad ke 9 H seorang nenek moyangnya bergelar Tuan maudud yang hijrah ke india. Orang

\footnotetext{
${ }^{5}$ Kesuma dkk, Op.Cit., hlm 326

${ }^{6} \mathrm{Ibid}$.

${ }^{7}$ Ahmad Idris, Abu al-A'la Al Mawdudi; Sahafatun min Hayatihi wa Jihadihi, cet 1, alQahirah: al-Muktar al-Islami, 1979, hal 19
} 
ISTIGHNA, Vol. 3, No 1, Januari 2020 P-ISSN 1979-2824 E-ISSN 2655-8459

Homepage: http://e-journal.stit-islamic-village.ac.id/index.php/istighna

Chindi Ayu Shonia, Lia Hermawati Pemikiran Politik Abu A'la Almaududi

yang memiliki nama Maudud adalah Khawajah Qutbuddun Maudud yang merupakan pendiri tarekat Christi. ${ }^{8}$

Tentang keluarga, Al-Mawdudi sangat erat dengan dunia Sufi atau tarekat secara khusus, dan memiliki tradisi terdapat hubungan dan pengenalan rangkaian guru serta murid serta mengutamakan nasab. Selama kiprahnya seorang pemikir dan penulis, tidak kurang dari 130 buku yang dihasilkannya. Dari karya yang semakin banyak karya yang ditulis dengan bahasa Arab, Inggris dan Urdu, alMawdudi membahas berbagai disiplin ilmu: Tafsir, hadis, Sejarah, Politik, Hukum Islam, serta Ekonomi. Karya-karya al-Mawdudi ternyata mendapatkan tanggapan yang hangat dimasyrakat luas, tidak hanya di India dan Pakistan akan tetapi diseluruh dunia. Hal ini dibuktikan dengan hampir semua karya al-mawdudi telah diterjemahkan kedalam berbagai bahasa. ${ }^{9}$

Ayahnya berprofesi sebagai pengacara yang taat beragama sekaligus menjadi guru pertama bagi Maududi. Sang ayah, Ahmad Hasan pernah menempuh pendidikan di Universitas Aligarh, namun ayahnya hanya menempuh pendidikan sebentar dikarenakan pola pendidikan di Universitas tersebut adalah kebaratbaratan. Ketika menjadi seorang pengacara, beliau sangat selektif dalam memilih kliennya. Beliau enggan mengerjakan hal-hal yang menyimpang dari agama dan bertentangan dengan hati kecilnya, maka dari itu beliau banyak ditinggalkan oleh para kliennya.

Oleh karena itu beliau berhenti menjadi pengacara. Kemudian beliau lebih memusatkan pengajaran dan pendidikan untuk sang anak. Al-maududi mengawali pendidikannnya di rumah hingga tamat tingkat dasar. Setelah itu, beliau meneruskan pendidikannnya ke Madrasah Fauqaniyah yang menggabungkan pendidikan modern barat dengan pendidikan islam tradisional. Beliau dikenal

${ }^{8}$ Ali Mukti, Alam Pikiran Islam Modern di India dan Pakistan, Cet.II, Bandung: Mizan, 1995, hal 238

${ }^{9}$ Kesuma dkk, Op.Cit., hlm 329 
ISTIGHNA, Vol. 3, No 1, Januari 2020 P-ISSN 1979-2824 E-ISSN 2655-8459

Homepage: http://e-journal.stit-islamic-village.ac.id/index.php/istighna

Chindi Ayu Shonia, Lia Hermawati Pemikiran Politik Abu A'la Almaududi

sebagai anak yang cerdas serta merampungkan pendidikannya tepat waktu dan mendapatkan Ijazah Maulawi. ${ }^{10}$

Keinginan Maududi untuk melanjutkan pendidikan harus terkubur dikarenakan perekonomian dan keadaan ayahnya yang sakit. Kemudian beliau ikut ayahnya pindah ke Hyderabad, disana beliau dapat melanjutkan pendidikan di Dar al-ulum, di Deoband, sebuah institut tempat untuk mencetak para ulama yang kharismatik di India saat itu. Maududi menempuh pendidikannya hanya enam bulan saja, dikarekan harus merawat ayahnya yang sakit, namun akhirnya meninggal dunia. Al-Maududi terus belajar menambah ilmu secara mandiri, walaupun pendidikan formalnya terlah terputus. Hal ini bisa terjadi berkat kemampuannnya menguasai bahasa asing yaitu bahasa urdu (bahasa ibu), arab, persia, dan inggris. Sehingga dari kemampuannya ini beliau dapat belajar dari para ulama yang berpengalaman. ${ }^{11}$

Setelah tidak bersekolah lagi, Maududi bekerja sebagai Jurnlaisme. Pada 1918 beliau banyak menyumbangkan tulisan-tulisan dan mengirimnya ke surat kabar dengan menggunakan bahasa urdu. Saat usia 7 tahun beliau menjadi editir harian Taj, Jabalpur, lalu menjadi editor di Al-Jami'ah, Delhi, yang merupakan satu surat kabar Muslim India yang populer pada abad ke 19-20. Tahun 1929 ketika beliau berumur 26 tahun, beliau telah menerbitkan sebuah karya yang cemerlang dan fenomenal, yaitu al-jihad fi al-islam (Perang Suci Dalam Islam). Buku ini belum pernah ada sebelumnya di literatur islam dan tidak ada bandingannya walaupun dalam bahasa arab. Maududi pindah ke Hyderabad (Deccan) serta tahun 1932 mulai menerbitkan Tarjuman Al-qur'an jurnal bulanan yang dipersembahkannya demi kebangkitan islam. Jurnal ini menjadi pelopor untuk kebangkitan kembali kaum elit terpelajar India. ${ }^{12}$

${ }^{10}$ Muhammad Iqbal, Implementasi Pemikiran Politik Abu Al A'la Al-Maududi Dalam Dinamika Politik Kontemporer, Jakarta: UIN Syarif Hidayatullah, 2006, hlm 16

${ }^{11}$ Ibid.

${ }^{12}$ Rahmena hal 106 dlm Muhammad Iqbal, Implementasi Pemikiran....., hlm 16 
ISTIGHNA, Vol. 3, No 1, Januari 2020 P-ISSN 1979-2824 E-ISSN 2655-8459

Homepage: http://e-journal.stit-islamic-village.ac.id/index.php/istighna

Chindi Ayu Shonia, Lia Hermawati Pemikiran Politik Abu A'la Almaududi

Pakistan menjadi negara merdeka pada tahun 1947, Maududi pindah di Pakistan dan muncul sebagai tokoh pejuang yang berusaha menjadikan islam sebgai pedoman hidup dan inti dari konstitusi negara yang baru merdeka itu. Beliau melihat bahwa pendiri Pakistan, seperti Ali janah lebih tidak konsisten dalam menerapkan islam dalam kehidupan bernegara. Sebagai ancaman oleh para penguasa begitulah pejuang politik maududi di pandang. Hal ini menyebabkan Maududi sebanyak empat kali ditahan dan masuk penjara pada tahun 1948-1967. Penahanan dilakukan karena oposisi yang beliau lakukan kepada penguasa di Pakistan. ${ }^{13}$

Selain menjadi pejuang politik, Maududi juga berjuang dalam dakwah sebgai seorang da'i, semua kegiatan dakwanya dipusatkan pada kepentingan untuk mewujudkan cita-citanya, yaitu islam sebagai pedoman hidup. Disamping berdakwah, beliau menyisihkan waktu untuk mengajar di Fakultas Theologi di Islamic Collage, Lahore. Selain menjadi seorang Da'i beliau juga merupakan seorang ilmuan yang telah menciptakan banyak karya ilmiah, diantaranya : Al-jihad fi al-Islam 1927, Risala-I Diniyah 1932, Tafhim Al-Qur'an, 1942-1972, first Principle of the Islamic state 1968 Fundamentalisme of Islam 1960, Islamic Law and Constitution 1960, Islamic wayof life 1967, The Moral Foundamentalis of the Islamic Moment Constitutions 1952, The political theory of Islam (Ltd), The Process of the Revivalist Movement in Islam 1963, Toward Understanding Islam 1948, The true Conduct of life 1962, Unity of the Muslim World $1967 .{ }^{14}$

Pendirian negara Islam menurut Al-Mawdudi haruslah diperjuangkan dimanapun dan melalui cara apapun, jika kita berkeinginan menjalankan syariat Islam dalam dunia kenyataan. Beliau merasa yakin bahwa dengan adanya negara Isam, ajaran islam yang sempurna bisa mewujudkan cita-cita Islam menjadi sebuah negara yang damai dan sejahtera, dan hal ini adalah cita-cita oleh Islam sendiri dalam Al-Quran. ${ }^{15}$

\footnotetext{
${ }^{13}$ Ainur Ropik, Op.Cit., Hlm 175

${ }^{14}$ Ibid.

${ }^{15}$ Kesuma dkk, Op.Cit., hlm 333
} 
ISTIGHNA, Vol. 3, No 1, Januari 2020 P-ISSN 1979-2824 E-ISSN 2655-8459

Homepage: http://e-journal.stit-islamic-village.ac.id/index.php/istighna

Chindi Ayu Shonia, Lia Hermawati Pemikiran Politik Abu A'la Almaududi

Menurut Maududi islam adalah sebuah prinsip moral etika, serta berbagi petunjuk dibidang politik dan ekonomi. Beliau menyimpukan bahwa islam tidak hanya suatu kepercayaan, namun merupakan suatu sistem yang lengkap dan didalamnya terkandung semua jawaban terhadap masalah yang dialami oleh ummat manusia. ${ }^{16}$ Maududi memepertegas bahwa semua ini tidak dapat diterjemahkan menjadi suatu tindakan praktis kecuali ada jaminan untuk pelaksanaannya. Ketika umat muslim berkringinan untuk mendirikan agama Tuhan tidak cukup hanya dengan mendirirkan sholat, puasa, zakat, dan haji.

Nama abul A'la Al-Maududi tidak mungkin dapat dipisahkan dari cita-cita kebangkitan Islam pada abad ke-15 Hijriyah sekarang ini. Suatu cita-cita yang telah merata di seluruh polosok Dunia Islam. Dapat dikatakan bahwa Al-Maududi merupakan salah satu tokoh pembaharu pemikiran Islam yang gagasan dan citacitanya telah berpengaruh besar pada fenomena pembangunan Islam dewasa ini.

Salah satu hal penting yang mempengaruhi pemikiran Maududi dari ibnu taimiyah yaitu "keharusan pelaksanaan ajaran syari'ah secara penuh dalam kehidupan masyarakat maupun pribadi”. bercermin dari pemikiran itu maududi menyimpulkan bahwa pekerjaan penting dalam pembaharuan masyarakat dan pemerintah dengan cara memperbarui pelaksanaan Syari'ah dan memperpendek jarak perbedaan antara teori daan praktik. Beliau juga mengatakan dengan dasar pemikiran ini bahwa pekerjaan pemerintah dan agama sebaiknya didak dipisahkan. $^{17}$

Mengenai konsep pemikiran al-Mawdudi tentang negara dilatarbelakangi oleh konsepnya tentang kebutuhan akan sebuah kekuasaan dalam rangka mewujudkan pesan-pesan dalam al-Quran dalam kehidupan nyata. Karena menurutnya, al-quran tidak hanya meletakkan sikap dan etika semata, tetapi juga memberikan bimbingan-bimbingan dalam politik,sosial, dan ekonomi. Juga ditetapkan tentang hukuman untuk tindak yang tidak baik, juga ditetapkan prinsip

\footnotetext{
${ }^{16}$ Ainur Ropik, Op.Cit., Hlm 177

${ }^{17}$ Ibid., hlm 175
} 
ISTIGHNA, Vol. 3, No 1, Januari 2020 P-ISSN 1979-2824 E-ISSN 2655-8459

Homepage: http://e-journal.stit-islamic-village.ac.id/index.php/istighna

Chindi Ayu Shonia, Lia Hermawati Pemikiran Politik Abu A'la Almaududi

kebijaksanaan keuangan. Semua ini tidak dapat diwujudkan serta dipraktekkan dalam kehidupan sehari-hari, kecuali ditegakkan dalam suatu negara islam. Dalam hal ini al-mawdudi menyatakan perihal pentingnya pembentukan suatu negara islam sebagai raelisasi dari sayariat islam yang telah di tentukan dalam Al-quran. Konsep tersebut terdapat dalam Q.S: Al-Nur:2. ${ }^{18}$

Beliau mengembangkan gagasan mengenai Wahyu Allah dengan untuk menegaskan keutamaan ajaran islam, setelah penolakannya terhadap pandangan barat. Sehingga pandangan yang digunakan pemimpin islam yang berpengetahuan barat menjadi berpandangan islam. Menurutnya pandangan barat tidak hanya bertentang dengan pandangan islam, tetapi mengancam kepentingan muslim. Padahal islam adalah agama yang mencakup semua aspek kehidupan manusia, seperti islam memiliki kekuatan sosio-politik yang efektif dan ungul untuk menggantikan pandangan barat seperti kapitalisme dan sosialisme. ${ }^{19}$

Ideologi maududi semakin agamamis, beliau berpendapat bahwa pandangan islam tidak dapat di tandingi oleh pemikiran manusia, sehingga tidak ada lagi dalih bagu umat islam untuk menggunakan pandangan barat lagi, yang hanya merupakan gambaran dari manusia. Di balik kritiknya yang tajam terhadap pandangan barat, Maududi masih memakai istilah-istilah barat, misalnya revolusi islam, Negara Islam, dan Ideologi Islam.

Al-Mawdudi menurutnya agama islam melalui al-Quran tidak hanya terkait dengan perihal ibadah saja layaknya Shalat,Puasa, Haji, serta Zakat, juga hukum negara dan lembaga kenegaraaan. Apabila hendak mendirikan agama Allah, maka tujuan tersebut tidak akan dapat dicapai dengan shalat dan puasa saja,melainkan juga haruslah menegakkan hukum Ilahi dan menjadikan Syariat sebagai undangundang negara. Apabila jika tidak ditegakkan meskipun pranata Salat dan sebagainya sudah dikerjakan tidak akan menyebabkan ditegakkannya agama. Ia hanyalah penegakan secara din, bukan din secara penuh. Apabila yang ditegakkan

\footnotetext{
${ }^{18}$ Kesuma dkk, Op.Cit., hlm 331

19 Adiguna, Pemikiran Politik Sayyid Abul A'la AlMaududi dan Kontribusinya bagi Pakistan, Skripsi, Yogyakarta: Fakultas Adab UIN Sunan Kalijaga, 2009, hlm 5
} 
ISTIGHNA, Vol. 3, No 1, Januari 2020 P-ISSN 1979-2824 E-ISSN 2655-8459

Homepage: http://e-journal.stit-islamic-village.ac.id/index.php/istighna

Chindi Ayu Shonia, Lia Hermawati Pemikiran Politik Abu A'la Almaududi

malah hukum-hukum lain selain hukum Tuhan, maka yang terjadi alah penolakan atas din itu sendiri. Ayat Al-Qur'an menjadi sandaran oleh al-Mawdudi adalah (QS: al-Isra': 80$){ }^{20}$

Al-Mawdudi paham bahwa ayat ini yang berbunyi "berilah aku sebuah kekuasaan dan bantuan dari pemerintah yang memiliki kekuasaan yaitu negara, sehingga dengan dibantu kekuasaan tersebut serta sumber-sumber kekuasaan yang memaksa negara-mampu menegakkan kebajikan, membasmi kejahatan, meumbangkan korupsi, kecabulan dan dosa, meluruskan hal-hal yang bengkok yang sudah menjalar di kehidupan sosial serta mengatur keadilan sesuai dengan hukum yang telah diwahyukan". Tetapi apabila kekuasaan yang dicari adalah untuk menegakkan din Allah, maka tentulah ia merupakan tindakan ilahiyah dan saleh maka sama sekali tidak boleh dicampu adukkan dengan kekuasaan dan kehausan. ${ }^{21}$

Revolusi islam pada pemikiran A'la Maududi, merupakan pertentangan antara kekufuran dan islam. Sebuah perubahan yang mempunyai tujuan untuk mendasarkan nilai-nilai islam ke dalam kehidupan masyarakat, beiringan dengan mengahapus dampak dari ideologi ataupun hal-hal lain yang berada di luar konteks islam dan yang dapat merusak ajaran islam. Saat revolusi itu tercapai akan mengagas perubahan secara besar-besaran dalam masyarakat. Masa kejayaannya adalah dengan berdirinya sebuah negara islam yang mendasarkan akidah islam sebagai undang-undangnya.menurut Maududi dengan menggunakan ajaran islam yang mempunyai kekuatan politik dan hukum bagi insan, baik secara individu ataupun kelompok. ${ }^{22}$

Pada tahun 1948, Maududi memberikan 5 tausyiah melalui Radio Pakistan, yang dimaksudkan untuk untuk seluruh umat islam tidak hanya di Pakistan, melainkan untuk umat islam di seluruh dunia. Tausyiah tersebut mencakup 5 aspek pokok di kehidupan muslim, yaitu aspek moral, politik, spiritual, ekonomi, dan

20 Muhammad, Akbar, Abu al-A'la al-Mawdudi; Tafhimal-Quran, Vol. Viii, Lahore: Islamic, 1989, hlm 57

${ }^{21}$ Ibid., hlm 638

${ }^{22}$ Adiguna, Op.Cit., hlm 6 
ISTIGHNA, Vol. 3, No 1, Januari 2020 P-ISSN 1979-2824 E-ISSN 2655-8459

Homepage: http://e-journal.stit-islamic-village.ac.id/index.php/istighna

Chindi Ayu Shonia, Lia Hermawati Pemikiran Politik Abu A'la Almaududi

sosial. Dari kelima tausyah tersebut kemudian diterbitkan menjadi buku yang berjudul Islamic Way of life oleh Islamic Research Academy. ${ }^{23}$

Pada tahun 1937, beliau baru benar-benar terlibat lebih dalam dan langsung mengenai persoalan politik. Saat itu, india berada di gerbang pintu kemerdekaan setelah kurang lebih 150 tahun dijajah oleh kerajaan Inggris. Dalam keadaan itu, beliau menyadari bahaya yang mengancam eksistensi umat islam. ${ }^{24}$

Tanggal 28 maret 1953, Maududi di tangkap dan dipenjara akibat tulisannya yang berjudul The Qadiani Problems yang memiliki tujuan untuk memberikan dukungan terhadap tuntutan rakyat yang berkeinginan agar masyarakat Qadiani harus diperlakukan sebagai kelompok minoritas atau non-muslim pada konstitusi Pakistan, namun pemerintah tidak menyetujui tututan tersebut dan Maududi di uduh sebagai penghasut. Maududi di jatuhi hukuman gantung oleh pengadilan. Mendengar vonis tersebut Maududi tak sedikitpun gentar, dan beliau berkata: "Jika ajal saya telah tiba, tak seorangpun dapat mencegah saya darinya. Dan jika ajal saya belum tiba, mereka tidak dapat menggiring saya ke tiang gantungan meskipun mereka menggantung diri mereka sendiri untuk menggantung saya”. Akibat dari desakan dan protes dari kaum muslimin dari dalam ataupun luar negeri, akhirnya pemerintah merubah keputusan pengadilan tersebut menjadi 14 tahun penjara. Namun pada 25 mei 1955, Maududi dinyatakan bebas oleh pengadilan tinggi dikarenakan uu yang membuatnya ditahan telah dibatalkan. Walupun kerapkali ditahan, namun perjuangan agar berdirinya negara islam Pakistan dapat terwujud tak pernah berhenti. ${ }^{25}$

Menjadi seorang pemikir islam beliau sangat memperhatikan paham dan ajaran islam. Berdasarkan al-qur'an dan sunnah, beliau selalu berusaha membangun paradigma pemikiranya. Maududi merupakan seorang pemikir yang fundamentalis, yang berpikiran bahwa islam merupakan agama yang lengkap dan sempurna.

\footnotetext{
${ }^{23}$ Muhammad Iqbal, Op.Cit., hlm 16

${ }^{24}$ Ibid., hlm 20

25 Ibid., hlm 22
} 
ISTIGHNA, Vol. 3, No 1, Januari 2020 P-ISSN 1979-2824 E-ISSN 2655-8459

Homepage: http://e-journal.stit-islamic-village.ac.id/index.php/istighna

Chindi Ayu Shonia, Lia Hermawati Pemikiran Politik Abu A'la Almaududi

Seperti mana para ulama yang berpikiran fundamentalis lainnya, Maududi kembali ke masa lalu dan kaum modern melihat ke masa depan. Dua kelompok tersebut menganggap sebagai reformis atau pembaharu, namun medernisasi yang mereka lakukan berbeda. Maududi masuk ke dalam kaum fundamentalis yang berusaha agar islam tetap diterapkan kembali pada masa klasik.

Perbedaan pemikiran Maududi dengan pemikiran kaum fundamentalis lainnya. Hal ini karena Maududi bergerak dalam aspek kenegaraan. Dalam aspek ini, ada sejumlah konsep Maududi yang membuatnya berbeda dengan kaum konservatif ataupun dengan kaum modernis. Contohnya konsepsi kedaulatan Tuhan dalam negara islam. Interpretasi ini menunculkan faham theo-demokrasi, yaitu kekuasaa Tuhan berada di tangan umat islam yang melakukan sesuai dengan $\mathrm{Al}$ qur'an dan sunnah. Dalam konsepsi khilafah, Maududi mempunyai pendapah bawah seorang laki-laki ataupun perempuan dapat menjadi khilafah, jadi tidak hanya kepala negara yang dapat menjadi khilafah. ${ }^{26}$

Konsep Maududi mengenai negara islam didasarkan atas Syariah, yang mengkontribusikan dogma-dogma dasarnya. Dalam pandangan syariah, bagi Maududi terdapat 4 dogma yang manjadi dasar negara islam: mengklaim kedaulatan Tuhan, mengklaim otoritas Nabi, mengklaim status perwakilan Tuhan dan melakukan musyawarah bersama (mutual consultation).

Jadi negara islam berdasarkan konsep Maududi adalan negara teokratis. Namun dengan tetap menekankan pada musyawarah bersama maka negara ini juga bersifat demokratis. Dengan theo-demokrasi Maududi menginginkan manifestasi terhadap konsep antitesis atas demokrasi Barat Sekuler yang baginya hanya berdasarkan pada kedaulatan rakyat, serta dikarenakan itu bertentangan dengan Islam. Negara islam bertumpu pada dua prinsip: kedaulatan (sovereighty) Tuhan dan perwakilan (vicegerency) manusia.

${ }^{26}$ Ibid., hlm 26 
ISTIGHNA, Vol. 3, No 1, Januari 2020 P-ISSN 1979-2824 E-ISSN 2655-8459

Homepage: http://e-journal.stit-islamic-village.ac.id/index.php/istighna

Chindi Ayu Shonia, Lia Hermawati Pemikiran Politik Abu A'la Almaududi

Dari sudut pandang Al-Mawdudi, pemerintahan harus seperti masa Khalifah al-Rasyidin. Tetapi jika dilihat pada perumusan konstitusi dalam dewan konstituante 1956, dan dalam rumusan tersebut mencantumkan nama "Republik Islam Pakistan". Dan al-mawdudi menyetujui hal ini, walaupun dalam konsepnya al-Mawdudi menghendaki bentuk negara seperti khalifah al-Rasyidin akan tetapi dia menyetujui bentuk pemerintahan negara republik. ${ }^{27}$

Pokok pikiran dari Maududi mengenai kenegaraan, dilihat dari banyak pemikiran mengenai politik islam, hanya Maududi yang mengemukakan konsep kenegaraan yang lebih rinci dan lengkap. Terdapat 3 pokok dasar yang menjadi landasan dalam pemikiran Maududi mengenai kenegaraan antara lain menurut islam:

1. Islam merupakan agama yang lengkap, dengan segala petunjuk untuk setiap aspek kehidupan manusia, termasuk kehidupan politik. Yang berarti dalam islam ada sistem politiknya. Jadi umat islam jika ingin berpolitik tidak perlu atau bahkan tidak boleh menggunakan politik dari barat. Hanya cukup menggunakan sistem politik islam dengan merujuk pada politik pada masa Khulafaur Ar Rasyidin sebagai model politik islam.

2. Kekuasaan tertinggi yang terdapat di istilah politik disebut kedaulatan, adalah pada Allah, insan hanya sebagai pelaku dari kedaulatan Allah tersebut sebagai khalifah Allah di bumi, maka dari itu kedaulatan rakyat tidak dapat dibenarkan, sebagai khalifah Allah di bumi, manusia dan negara seharusnya mematuhi hukum-hukum yang terdapat dalam Al Qur'an dan Sunnah Rasul. Yang dimaksud khalifah disini adalah laki-laki islam dan perempuan islam.

3. Sistem politik islam merupakan sistem unversal, tanpa mengenal batas, dan ikatan-ikatan geografi, bahasa dan kebangsaan. ${ }^{28}$

\footnotetext{
${ }^{27}$ Kesuma dkk, Op.Cit., hlm 334

${ }^{28}$ Muhammad Iqbal, Op.Cit., hlm 41
} 
ISTIGHNA, Vol. 3, No 1, Januari 2020 P-ISSN 1979-2824 E-ISSN 2655-8459

Homepage: http://e-journal.stit-islamic-village.ac.id/index.php/istighna

Chindi Ayu Shonia, Lia Hermawati Pemikiran Politik Abu A'la Almaududi

Dalam formula pemikiran Al Maududi, secara singkat model negara yang ditegakkan adalah pokok tahuhid (kemahaesaan Allah), risalah (Kerasulan Muhammad), dan yang terakhir Khalifah. Syarat-syarat penguasa:

1. Seorang muslim

2. Seorang laki-laki

3. Dewasa dan berakal

4. Warga negara dari negara islam dimana pemilihan itu berlangsung

Menurut al-Mawdudi cuma Amir lah satu-satunya yang dapat menerima ketaatan serta kesetiaan rakyat, rakyat juga telah mewakilkan sepenuhnya hak mereka untuk mengambil sebuah keputusan tentang semua masalah yang berkaitan dengan kebutuhan mereka. Kedudukan pemimpin menurutnya sangat berbeda dengan raja ataupun ratu layaknya di Inggris ataupun presiden bahkan perdana menteri. Didalam konsepnya, al-Mawdudi tidak menyebutkan bentuk pemerintahan yang bagaimana, ia hanya berkata bentuk pemerintahan yang ia gagas bukanlah seperti pemerintahan modern layaknya sekarang ini. Beliau juga menyampaikan bahwa bentuk konsep kedaulatan Tuhan (Teo-demokrasi) yang tepat diaksanakan apabila negara Islam nantinya terwujud di pakistan. ${ }^{29}$

Al-Mawdudi menempatkan Amir(pemimpin) negara islam sebagai pemegang kekuasaan tertinggi. Beban yang diemban seorang Amir bukan sekedar sebagai pemimpin eksekutif tetapi juga harus bertanggungjawab dalam urusan keagamaan. Pendapat Al-mawdudi tersebut didasari pada tradisi yang pernah dilakukan oleh Nabi pada masa Khulafa al-Rasyidin yakni "Amir" memiliki kewajiban menjadi imam dalam shalat fardu,dan menjadi Khatib disetiap salat jum'at di masjid tersebut. Dalam memilih seorang pemimpin harus memilih orang yang bertakwa. Pencalonan kepala negara (imarah) dipilih dari Muslim yang sudah dilihat biografinya, sikap, dan akhlak yang amanah oleh masyarakat. Apabila masyarakat telah menyetujui hal ini, maka calon baru diperbolehkan memimpin umat. Dan rakyat wajib mematuhi segala aturannya. Dan dalam pelaksanaan hukum

${ }^{29}$ Kesuma dkk, Loc.Cit. 
ISTIGHNA, Vol. 3, No 1, Januari 2020 P-ISSN 1979-2824 E-ISSN 2655-8459

Homepage: http://e-journal.stit-islamic-village.ac.id/index.php/istighna

Chindi Ayu Shonia, Lia Hermawati Pemikiran Politik Abu A'la Almaududi

seluruhnyya bersandar pada Khlifah dan khalifah berjanji pada syariat yang telah digariskan oleh Al-Quran dan Hadist Rasulullah saw. ${ }^{30}$

Al-Mawdudi memaparkan mengenai sikap yang mesti dimiliki oleh seorang pemimpin dalam menjalankan suatu pemerintahannya yaitu: selalu memperhatikan asas musyawarah dan menetapkan peraturan, peraturan harus berdasarkan pada suara terbanyak berdasarkan rapat anggota MPR, lembaga pengadilan dan kejaksaan islam sepenuhnya berada pada luar aturan-aturan lembaga eksekutif, karena tugas seorang hakim adalah melaksanakan undang-undang Alllah untuk umatnya. Pemikiran al-Mawdudi tentang Amir cukup menarik, karena Amir berada pada kedudukan lembaga eksekutif. Pemikiran al-Mawdudi berbeda dengan mekanisme struktur negara yang berkembang di dunia modern. Menurutnya, model seperti inilah yang membedakan antara sistem negara yang diterapkan didunia barat dengan model negara islam. ${ }^{31}$

Mengenai lembaga eksekutif, tugas dari lembaga eksekutif ialah menegakkan pedoman-pedoman Tuhan yang disampaikan melalui al-quran serta sunnah serta menyiapkan masyarakat agar mengakui dan menganut pedoman yang telah ditetapkan agar dijalankannya dalam kehidupan sehari-hari. Menurutnya, kata ulul amri dan umara dalam al-qur'an dan hadits untuk menyatakan lembaga eksekutif. Dalam lembaga eksekutif, menurutnya tidak hanya kepala negara saja, tetapi ada beberapa pejabat yang berfungsi membantu tugas kepala negara atau jika disepadankan bisa disebut dengan menteri. Secara harfiah Ahl al-Hal wa-Aqd sebagai badan legislatif berarti orang yang bisa memutuskan serta mengikat. Sedangkan para ahli fikih siyasah mendefinisikan Ahl-al-Hal wa-Aqd sebagai orang yang berhak menentukan serta memutuskan dan menentukan sesuatu atas nama warga negaranya. Dengan demikian Ahl al-Hal wa-Aqd adalah lembaga perwakilan yang menampung serta menyalurkan harapan suara masyarakat. ${ }^{32}$

\footnotetext{
${ }^{30}$ Ibid., hlm 335

${ }^{31}$ Ibid., hlm 337

${ }^{32}$ Ibid., hlm 338
} 
ISTIGHNA, Vol. 3, No 1, Januari 2020 P-ISSN 1979-2824 E-ISSN 2655-8459

Homepage: http://e-journal.stit-islamic-village.ac.id/index.php/istighna

Chindi Ayu Shonia, Lia Hermawati Pemikiran Politik Abu A'la Almaududi

Langkah-langkah dalam pembentukan badan ini menurut al-Mawdudi sama dengan langkah pemilu yang dipratekkan zaman modern, sepanjang ia dipraktekkan pada zaman modern, sepanjang ia dipraktekkan dengan jujur dan bebas dari unsur kecurangan. Mekanisme pencalonan untuk menjadi Ahl al-Hal wa-Aqd secara otomatis harus mengikuti dan mendukung sang Amir.

Dalam konsepsi al-Mawdudi Ahl al-Hall wa-Aqd tidak sama dengan konsep yang ada dalam teori Trias Politica. Menurutnya, badan ini lebih dekat pada Majlis Syura. Fungsi utama badan ini adalah menjadi lembaga penengah dan pemberi fatwa , jika terdapat pedomen-pedoman yang jelas dari Allah dan Rasulnya, menegakkannya dalam suana dan bentuk pasal, menggunakan pengertian yang berkaitan serta rincian-rinciannya; ketika jika pedoman al-qur'an dan sunnah mempunyai kemungkinan interpretasi lebih dari satu, maka lembaga legislatif yang berhak memutuskan penafsiran mana yang harus ditempatkan dalam uud. Jika ada isyarat yang jelas dalam al-qu'an dan sunnah, fungsi lembaga ini adalah untuk menegakkan hukum yang berhubungan dengan masalah yang sama yang harus sesuai dengan hukum islam, jika al-qur'an dan sunnah tidak memberikan petunjuk atau tidak ada dalam konvensi. Khulafaur rasyidin, maka kita harus mengartikan bahwa Tuhan telah membiarkan kita bebas melakukan legalisa mengenai masalah ini menurut apa yang terbaik. ${ }^{33}$

Mengenai badan Qadi (hakim) menurut al-Mawdudi haruslah yang berdiri sendiri, pertunjukkan badan ini dilakukan secara langsung dilakukan oleh Amir.Tugas badan Qadi yaitu menentukan status hukum ,memeriksa serta menguji peraturan-peraturan yang diduga peraturan-peraturan yang diduga bertentangan dengan syariat. Badan ini secara penuh dapat membatalkan serta mengganti dengan hukum yang baru. Posisi Amir adalah pemegang kekuasaan tertinggi dalam suatu pemerintahan, tetapi dalam penentuan hukum yang berkuasa adalah Qadi.

Konsep dasar tentang struktur pemerintahan yang dirancang oleh Abu A'la Al-Mawdudi adalah konsep-konsep yang idelis,bahkan utopis. Konsep ini tidak

${ }^{33}$ Ibid., hlm 339 
ISTIGHNA, Vol. 3, No 1, Januari 2020 P-ISSN 1979-2824 E-ISSN 2655-8459

Homepage: http://e-journal.stit-islamic-village.ac.id/index.php/istighna

Chindi Ayu Shonia, Lia Hermawati Pemikiran Politik Abu A'la Almaududi

realistis dan sulit untuk diwujudkan dalamdunia nyata. Kondisi ini disadari oleh Abu a'la Al-Mawdudi dan ia tulis dalam bukunya bahwa konsep yang disusun akan terwujudkan secara maksimal apabila semua masyarakat telah dididik dengan ajaran-ajaran islam yang revolusioner.

Menurut Al-Mawdudi tujuan negara yang dikonsepsikan Al-qur'an tidaklah negatif tetapi positif. Tujuan negara tidak hanya mencegah rakyatnya saling memeras tetapi melindungi kebebasan mereka serta melindungi seluruh bangsa dari invasi asing. Negara mempunyai tujuan untuk mengembangkan sistem keadilan sosial yang berkeseimbangan yang tengah diketengahkan Allah dalam al-qur'an. Untuk mewujudkan misi ini maka menurut al-Mawdudi kekuasaan politik akan digunakan demi kepentingan itu apabila dirasa perlu, sarana propaganda dan persuasif damai akan digunakan, pendidikan moral juga dilaksankan, serta pengaruh sosial ataupun pendapat umum akan dijinakkan. ${ }^{34}$

Tujuan pembentukan negara adalah menegakkan suatu keadilan dalam kehidupan manusia serta menghentikan kedzaliman serta mengahncurkan kesewenang-wenangan. Tujuan pokok berdirinya negara islam ialah melaksanakan sistem keadilan sosial yang baik, seperti yang diperintahkan Allah dalam kitab-Nya, disamping itu juga menawarkan konsep-konsep maslahat yang diridhai oleh Allah. Al-Mawdudi menegaskan bahwa kejahatan yang tidak dapat dimusnahkan melalui ajaran-ajaran Qur'an yang membutuhkan kekuasaan memaksa dari pihak negara untuk melakukan pembasmian.

\section{E. KESIMPULAN}

Dari urutan diatas dapat disimpulkan bahwa Abu A'la al-Maududi adalah tokoh kharismatik yang disegani dalam memperjuangkan islam serta dapat memberi suasana pemikiran politik yang diimpikan dalam politik islam. Pemikiran politiknya mencita-citakan terwujudnya negara Islam yang berdasarkan pada AlQuran dan hadist. Oleh sebab itu, ia merumuskan sebuah kerangka aturan negara islam yang sangat komprehensif. Meskipun demikian, ia tidak memaksakan idenya

${ }^{34}$ Ibid., hlm 341 
ISTIGHNA, Vol. 3, No 1, Januari 2020 P-ISSN 1979-2824 E-ISSN 2655-8459

Homepage: http://e-journal.stit-islamic-village.ac.id/index.php/istighna

Chindi Ayu Shonia, Lia Hermawati Pemikiran Politik Abu A'la Almaududi

tentang negara islam tersebut. Ia tidak dapat menerima bentuk serta model negara lainnya . Namun yang penting baginya kedaulatan yang dianut adalah kedaulatan kedaulatan Tuhan (teo-demokrasi) sebagai ciri negara islam. Tidak seperti model negara republik pada umumnya yang memakai sistem kedaulatan rakyat atau demokrasi.

Lebih lanjut,al-Mawdudi membangun konsep politiknya dengan istilah Amir, Ahl Hall wal-Aqd dan Qadi. Ketiga badan inilah yang memegang kekuasaan dalam negara islam. Ia menggunakan istilah Amir untuk posisi Kepala negara atau lembaga eksekutif. Kemudian Ahl-al-Hall Wa al-Aqditempatkan sebagai badan legislatif dan Qadhi sebagai badan yudikatif yang ditunjuk langsung oleh Amir .

Pada bagian ini merupakan jawaban dari tujuan penelitian secara jelas, sederhana, ringkas, tepat, padat, dan berisi, serta layak dipublikasikan dalam jurnal. Jangan mengulang abstrak, atau hanya daftar hasil dan pembahasan. Simpulan dapat bersifat generalisasi temuan sesuai permasalahan penelitian, selain itu juga terdapat rekomendatif untuk langkah selanjutnya.

Pola dan formula pemikiran politik al-Maududi yang ada dalam dinamika masyarakat Pakistan memberikan sumbangsih positif kepada masa depan politik islam, dimana islam hadir sebagai sistem sosial kemasyarakatan atau bahkan memberi gambaran dan bayangan budaya islam serta mengatur sistem kemasyarakatan dan ketatanegaraan. Sehingga msngahantarkan al-Maududi menjadi figur pemurni atau kita kenal sebagai fundamentalis dalam sejarah pemikiran islam melalui gerakan-gerakan revolusioner yang islami dan yang masih tetap hangat didiskusikan kapanpun dan dimanapun

\section{REFERENSI}

Ahmad, Idris.1979. Abu al-A'la Al Mawdudi; Sahafatun min Hayatihi wa Jihadihi,cet 1, al (al-Qahirah; al-Muktar al-Islami.

Iqbal, Muhammad, 2006. Implementasi Pemikiran Politik Abu Al A'la Al-Maududi Dalam Dinamika Politik Kontemporer. Jakarta: UIN Syarif Hidayatullah 
ISTIGHNA, Vol. 3, No 1, Januari 2020 P-ISSN 1979-2824 E-ISSN 2655-8459

Homepage: http://e-journal.stit-islamic-village.ac.id/index.php/istighna

Chindi Ayu Shonia, Lia Hermawati Pemikiran Politik Abu A'la Almaududi

Kesuma dkk, 2015. Pemikiran Politik Abu A'la Al Mawdudi. IAIN Raden Intan Lampung.

Mukti, Ali. 1995. Alam Pikiran Islam Modern di India dan Pakistan.Cet.II. Bandung . Mizan

Muhammad, Akbar. 1989. Abu al-A'la al-Mawdudi, Tafhimal-Quran. Vol. Viii, Lahore:Islamic

Ropik, Ainur, 2012. Studi Komparasi Pemikiran Abul A'la Maududi Dengan Muhammad Natsir Tentang Konsep Negara Islam. Palembang: IAIN Raden Fatah

Mestika, Zed, 2004. Metode Penelitian Kepustakaan, Jakarta: Yayasan Obor Indonesia,

Adiguna, 2009. Pemikiran Politik Sayyid Abul A 'la AlMaududi dan Kontribusinya bagi Pakistan, Skripsi, Yogyakarta: Fakultas Adab UIN Sunan Kalijaga 